REPORT

\title{
How does B cell depletion therapy work, and how can it be improved?
}

\author{
E A Clark, J A Ledbetter
}

Ann Rheum Dis 2005;64:iv77-iv80. doi: 10.1136/ard.2005.042507

The past few years have seen a surge of interest in B cell depletion therapy for patients with rheumatoid arthritis. This paper outlines the possible mechanism(s) by which B cell depletion therapy works. It is likely there is more than one mechanism and the relative importance of each mechanism depends on the target cell. These include CD20-induced apoptosis, complement dependent cytotoxicity, antibody dependent cell-mediated cytotoxicity, and selective targeting and depletion of $B$ cell subsets. The implications of these mechanisms in the further improvement of $B$ cell depletion therapy in rheumatoid arthritis and other autoimmune diseases are discussed.

$\mathrm{T}$ he major goal of B cell depletion therapy is to destroy malignant $\mathrm{B}$ lineage cells or autoimmune disease producing B cells in patients with cancers or autoimmune diseases, while at the same time retaining protective $\mathrm{B}$ cell immunity. For many years rheumatologists have debated how B cells contribute to the development of rheumatoid arthritis (RA) and whether depleting B cells in patients might be therapeutic. In a landmark study, Shlomchik et al showed that autoimmune-prone MRL-lpr/lpr mice lacking B cells do not develop autoimmune kidney destruction, vasculitis, or autoantibodies. They concluded that their "data demonstrate that B cells could be an important target for therapy of systemic autoimmunity" and that "elimination of B cells or B cell subsets would have distinct advantages over removal of Ig alone". They turned out to be right. In a follow up study ${ }^{2}$ Chan et al showed that MRL-lpr/lpr mice that have B cells but cannot make antibodies still develop autoimmune disease. This suggested that B cell depletion therapy might be able to work by removing B cell antigen presenting cells (APCs) presenting autoantigens as well by removing autoantibody producing B cells.

About the same time Edwards et al after suggesting a role for B cells in $\mathrm{RA}^{3}{ }^{4}$ began treating RA patients with the B cell depleting agent rituximab, a chimeric mouse/human recombinant monoclonal antibody that binds to CD20. Recently, Edwards et al ${ }^{5}$ reported sustained clinical improvement after rituximab treatment alone or in combination with cyclophosphamide or methotrexate. Thus, B cell depletion appears to be therapeutic in some patients with RA as well as in other autoimmune diseases. ${ }^{67}$ The key questions we address here are:

- How does B cell depletion therapy work?

- How can it be improved?

\section{A FEW HISTORICAL COMMENTS}

The structure and properties of CD20 have been reviewed recently. ${ }^{8}$ We wish to simply underscore others and our studies, which demonstrated that monoclonal antibodies (mAbs) to CD20 signal B cells. CD20 ligation can induce or block B cells from entering the cell cycle and can induce or block apoptosis. ${ }^{9}{ }^{10}$ These different outcomes may depend on the B cell stage, the CD20 mAb, the degree or state of CD20 clustering, whether CD20 is phosphorylated or not and other factors. While CD20 activates protein tyrosine kinase dependent signals, ${ }^{11}$ and downstream transcriptional responses, there remain unanswered questions regarding the biological function of CD20. For example, a number of factors regulate the phosphorylation of CD20: CD20 binding itself or CD40 signalling upregulate CD20 phosphorylation, and ligating the $\mathrm{B}$ cell receptor and interferon $\alpha$ downregulate phosphorylation. ${ }^{12-14}$ However, the function of CD20 phosphorylation remains unclear. It is possible that CD20 phosphorylation is involved in CD20 interactions with other receptors. After ligation with mAbs, CD20 moves into lipid rafts, and this entry into lipid rafts may be necessary for CD20 mAbs to induce apoptosis and mediate complement dependent lysis. ${ }^{15}{ }^{16}$ The point is that CD20 acts as much more than simply a docking site for mAbs. As we shall see, the outcome of $\mathrm{mAb}$ binding may depend on the state of the $\mathrm{B}$ cell and CD20 on the B cells.

\section{HOW DOES B CELL DEPLETION THERAPY WORK IN VIVO?}

The initial study by Press et $a l^{17}$ about 20 years ago showed that our mouse IF5 anti-CD20 mAb might be a useful therapeutic for B cell lymphoma but only if patients were treated with high doses $\left(100-800 \mathrm{mg} / \mathrm{m}^{2}\right.$ per day). Since this study and the studies showing that the chimeric CD20 mAb, rituximab, is an effective therapy for indolent $\mathrm{B}$ cell nonHodgkin's lymphoma (NHL), ${ }^{18} 19$ clinicians have asked "How does B cell depletion therapy work?" The short answer to this question is "By more than one mechanism". The long answer is "Different mechanisms may work together during B cell depletion, and the relative importance of each mechanism depends on the target cell".

\section{Apoptosis}

Rituximab clearly can induce apoptosis of chronic lymphocytic leukaemia (CLL) cells in vivo, ${ }^{20}$ and caspase- 3 activation (an indicator of apoptosis) was shown to be correlated with post-treatment lymphocyte counts. Whether or not patients with CLL have high or low affinity Fc $\gamma$ RIIIa or Fc $\gamma$ RIIa receptors does not influence clinical responses to rituximab, ${ }^{21}$ suggesting that in the case of CLL, antibody dependent cellmediated cytotoxicity (ADCC) may be less important than mechanisms such as apoptosis and complement dependent cytotoxicity for B cell depletion in this disease. In contrast,

Abbreviations: $A D C C$, antibody dependent cell-mediated cytotoxicity; APC, antigen presenting cell; CDC, complement dependent cyłotoxicity; $\mathrm{CLL}$, chronic lymphocytic leukaemia; mAb, monoclonal antibody; $\mathrm{NHL}$, non-Hodgkin's lymphoma; RA, rheumatoid arthritis 
ADCC may be a critical mechanism for depleting nonHodgkin's follicular B lymphoma cells and normal B cells (see below).

CD20 ligation may also make responsive B cells more susceptible to drug induced cell death. ${ }^{22}$ When lymphocytes are in the G0 stage of the cell cycle, there are likely to be at less risk to undergo apoptosis; but if they are dysregulated or induced to enter Gl, or are arrested in Gl, they are more likely to die. For instance, $\mathrm{T}$ cells missing the lung Kruppellike transcription factor (LKLF) spontaneously enter Gl and rapidly die..$^{23}$ Similarly, we have found that B cells that are caspase deficient spontaneously enter Gl and die more readily in vitro. ${ }^{24}$ Thus, one mechanism by which CD20 signalling may make B cells more susceptible to cytotoxic drugs or other cell depletion therapies may be triggering the $\mathrm{B}$ cells to enter into or remain in G1. In addition, CD20 binding may more readily induce death of memory B cells activated by toll-like receptor (TLR) signals or cytokines.

\section{Complement dependent cytotoxicity}

CD20 mAbs differ in their ability to mediate complement dependent cytotoxicity (CDC), and the ability to mediate CDC correlates with the ability of the mAb to translocate CD20 to lipid rafts. ${ }^{16} \mathrm{CDC}$ activity is thought to be an important function that mediates malignant B cell depletion in CD20 directed therapy. For example, neither the lF5 mAb nor rituximab could cure $\mathrm{Clq}$ deficient mice or complement depleted mice with hCD20+ lymphomas. ${ }^{25} 26$ In addition, expression of the complement inhibitors CD55 and CD59 was found to be significantly elevated on CLL cells from patients who had not responded to rituximab therapy. ${ }^{27}$ Thus the ability of CD20 mAbs to kill tumour cells correlates with CDC activity and with the binding kinetics of the individual antibodies. ${ }^{28}$ However, activation of the complement cascade was also found to be correlated with the side effects of rituximab treatment. ${ }^{29}$ It is not yet clear whether CDC activity is important for depletion of B cell in autoimmune disease, and whether effective CD20 directed therapies with reduced CDC activity can be devised in order to prevent side effects of CD20 therapy, such as production of inflammatory cytokines.

\section{Antibody dependent cell mediated cytotoxicity}

ADCC is likely to be an important mechanism for CD20 based depletion of NHL B cells and normal B cells in vivo. NHL patients with a polymorphism in the gene encoding Fc $\gamma$ RIIIa (CD 16a) leading to a higher affinity for CD16 on NK cells and other ADCC mediating cells have on average a better response to treatment with rituximab than patients with the lower affinity CD16a. ${ }^{31}$ Furthermore, Fc $\gamma$ R deficient mice do not reject lymphoma xenografts when treated with rituximab, unlike wild-type controls ${ }^{32}$ and do not deplete normal B cells when given anti-mouse CD20 mAb. ${ }^{33}$ Thus ADCC mediated by Fc $\gamma \mathrm{R}$ is important for B cell depletion. FcR expressed on effector cells other than natural killer cells may also play a role. It has been shown that neutrophils contribute to the antitumour activity of rituximab ${ }^{34}$ in nude mouse xenograft studies. In addition, tumour cells could be lysed in vitro using a bispecific molecule that bound both CD20 and CD89, an FCR for IgA expressed on neutrophils. ${ }^{35}$

\section{Targeting B cell subsets}

An obvious target for B cell depletion therapy in autoimmune diseases are the B cell precursors of plasma cells producing autoantibodies or recently activated memory B cells on their way to become antibody producing cells. ${ }^{36}$ Chan et al's ${ }^{2}$ and others studies suggest that depletion of autoantigen presenting B cells may reduce autoimmune disease progression. Furthermore, B cell APCs in inflamed synovium or cytokine producing $\mathrm{B}$ cells near or in the synovium may also be targets of CD20 based therapy. ${ }^{37}$ Less well appreciated perhaps is the important role B cells almost certainly play in directing the formation of extrafollicular germinal centres, which can be found in synovial tissue from patients with RA, Helicobacter pylori infected stomach mucosa, pseudo B cell lymphoma of the skin, and other sites. ${ }^{38}$ Just as B cells and T cells talk to each other in what we have termed "reciprocal dialogues", 39 it is also likely that B cells direct stromal cell elements to develop into extrafollicular dendritic cells. Since B cellfollicular dendritic cell dialogues contribute to development of extrafollicular germinal centres, removal of B cells by CD20 based therapy may not only destroy existing germinal centres but also prevent B cell programming of stromal cells and the development of new germinal centres in synovia.

A single short course of rituximab can lead to longlasting depletion of blood B cells for up to 48 weeks without significantly affecting serum Ig levels. ${ }^{5}$ Thus, it is important to understand both how B cell depletion can be so longlasting and also why not all B cells are necessarily depleted. A recent study using transgenic mice expressing human CD20 suggests that the efficacy of B cell depletion therapy may depend on whether the therapy can affect B cell homoeostasis. ${ }^{40}$ The anti-hCD20 treatment was most effective in mixed chimeras, where hCD20-negative B cells were present, which presumably could compete with hCD20+ B cells. AntiCD20 and BAFF-R-Fc worked together to deplete MZ B cells, suggesting disruption of homoeostasis, although BAFF might improve the efficiency of CD20 based depletion. This would in part explain why CD20 based B cell depletion can last so long.

Using anti-mouse CD20 mAbs Hamaguchi et al ${ }^{41}$ found that peritoneal Bla and Blb B cells, even though they were bound by mAbs, were not depleted as efficiently as B2 B cells. Furthermore, B cells in human CD19 transgenic mice were also not effectively depleted. B cells from huCD19 transgenic mice differ from normal B cells in that they have higher levels of spontaneous B cell receptor signalling including PI3 kinase activity. ${ }^{42}$ These results demonstrate that $\mathrm{B}$ cell depletion is not simply a passive process. Even in a system that is FC receptor dependent, ${ }^{33}$ the efficiency of $\mathrm{B}$ cell depletion may depend on the signalling state of the cell.

\section{HOW MIGHT B CELL DEPLETION BE IMPROVED FOR THERAPY OF AUTOIMMUNE DISEASE?}

Clearly, the answer to this question must be based on further understanding of just how and where B cell depletion can work. If pathogenic B cells reside in synovial tissue, it may be possible to improve therapy by more selectively targeting these cells. This may be possible by engineering a molecule that is smaller than an antibody to allow better access to B cells in tissues outside the blood. Another approach would be to selectively deplete subsets of B cells by choice of a target antigen other than CD20.

Another significant improvement could be achieved by reducing the infusion reactions associated with rituximab therapy. This may be possible by reducing CDC activity while retaining or enhancing ADCC activity. However, the degree to which toxicity can be reduced without sacrificing efficacy of CD20 therapy is not yet clear.

If the efficacy of B cell depletion does in fact depend on the signalling state of the B cells, ${ }^{40}{ }^{41}$ then combining therapies that target different signalling pathways could be efficacious. For instance, it may be beneficial to combine CD20 based therapy with a therapy targeting another B cell surface molecule, which triggers a signalling pathway distinct from that of CD20. Alternatively, it may be useful to obtain a "signalling profile" from NHL or other B cell tumors before deciding what B cell depletion therapy might work best. 
A number of recent studies suggest that tumour development and progression are influenced not only by intrinsic changes within tumor cells leading to dysregulation of survival, death, or proliferation, but also by the presence and activation of inflammatory cells within tumours. For instance, using a colitis-associated tumor model Greten et a ${ }^{43}$ found that depletion of I- $\kappa B$ kinase- $\beta$ (IKK $\beta$ ) in intestinal epithelial cells, as expected, reduced tumour incidence (but not tumour sizes). However, deleting IKK $\beta$ in myeloid cells reduced the size of developing tumours, probably through reducing the expression of proinflammatory cytokines. Similarly, Dave et $a l^{44}$ found that the presence within follicular lymphomas of non-malignant immune cells with a monocyte/DC signature predicted poorer survival. Thus, it may be beneficial to combine CD20 based B cell depletion therapy with therapies that inhibit or deplete inflammatory cells.

\section{CONCLUSIONS}

It has been about 20 years since the first patients with NHL were treated with a CD20 based immunotherapy, ${ }^{17}$ and there is still much to learn about how to optimise therapy for patients with B cell cancer. And it has only been about six or seven years since the first patients with RA were treated with rituximab. ${ }^{5}$ This is a relatively short time. We are still in the "early days" of B cell depletion therapy and therapies designed to remove or alter specific cell types. The future will bring many new improvements in drug design and combination drug therapy based on further understanding of how B cell depletion works and how to optimise effector functions.

\section{ACKNOWLEDGEMENT}

We thank Dario Magaletti for technical support.

\section{Authors' affiliations}

E A Clark, Department of Immunology and National Primate Research Center, University of Washington, Seattle, WA, USA

J A Ledbetter, Trubion Pharmaceuticals, 2401 4th Avenue, Suite 1050, Seattle WA 98121, USA

This work was supported in part by NIH grant RR00166.

Competing interests: none declared

Correspondence to: E A Clark, Department of Immunology and National Primate Research Center, Box 357330, University of Washington, Seattle WA 98195, USA; eclark@bart.rprc.washington.edu

\section{REFERENCES}

1 Shlomchik MJ, Madaio MP, Ni D, Trounstein M, Huszar D. The role of B cells in lpr/lpr-induced autoimmunity. J Exp Med 1994;180:1295-306.

2 Chan OT, Hannum LG, Haberman AM, Madaio MP, Shlomchik MJ. A novel mouse with $B$ cells but lacking serum antibody reveals an antibodyindependent role for B cells in murine lupus. J Exp Med 1999:189:1639-48.

3 Edwards JC, Cambridge J. Is rheumatoid arthritis a failure of B cell death in synovium? Ann Rheum Dis 1995;54:696-700.

4 Edwards JC, Cambridge G, Abrahams VM. Do self-perpetuating B lymphocytes drive human autoimmune disease? Immunology 1999;97:188-96.

5 Edwards JC, Szczepanski L, Szechinski J, Filipowicz-Sosnowska A, Emery P, Close DR, et al. Efficacy of B-cell-targeted therapy with rituximab in patients with rheumatoid arthritis. N Engl J Med 2004;350:2572-81.

6 Edwards JC, Cambridge G. Prospects for B-cell-targeted therapy in autoimmune disease. Rheumatology (Oxford) 2005;44:151-6.

7 Cope AP, Feldmann M. Emerging approaches for the therapy of autoimmune and chronic inflammatory disease. Curr Opin Immunol 2004;16:780-6.

8 Cartron G, Watier H, Golay J, Solal-Celigny P. From the bench to the bedside: ways to improve rituximab efficacy. Blood 2004; 104:2635-42.

9 Valentine MA, Licciardi KA. Rescue from anti-lgM-induced programmed cell death by the $B$ cell surface proteins CD20 and CD40. Eur J Immunol 1992;22:3141-8.

10 Shan D, Ledbetter JA, Press OW. Signaling events involved in anti-CD20 induced apoptosis of malignant human B cells. Cancer Immunol Immunother 2000;48:673-83.
11 Deans JP, Schieven GL, Shu GL, Valentine MA, Gilliland LA, Aruffo A, et al. Association of tyrosine and serine kinases with the $B$ cell surface antigen $C D 20$. Induction via CD20 of tyrosine phosphorylation and activation of phospholipase C-gamma 1 and phospholipase C-gamma 2. J Immunol 1993; 151:4494-504.

12 Einfeld DA, Brown JP, Valentine MA, Clark EA, Ledbetter JA. Molecular cloning of the human B cell CD20 receptor predicts a hydrophobic protein with multiple transmembrane domains. EMBO J 1988;7:711-17.

13 Clark EA, Shu GL, Luscher B, Draves KE, Banchereau J, Ledbetter JA, et al. Activation of human $B$ cells. Comparison of the signal transduced by IL- 4 to four different competence signals. J Immunol 1989;143:3873-80.

14 Genot EM, Meier KE, Licciardi KA, Ahn NG, Uittenbogaart CH, Wietzerbin J, et al. Phosphorylation of CD20 in cells from a hairy cell leukemia cell line. Evidence for involvement of calcium/calmodulin-dependent protein kinase II. $\mathrm{J}$ Immunol 1993;151:71-82.

15 Deans JP, Li H, Polyak MJ. CD20-mediated apoptosis: signalling through lipid rafts. Immunology 2002;107:176-82.

16 Cragg MS, Morgan SM, Chan HT, Morgan BP, Filatov AV, Johnson PW, et al. Complement-mediated lysis by anti-CD20 mAb correlates with segregation into lipid rafts. Blood 2003;101:1045-52.

17 Press OW, Appelbaum F, Ledbetter JA, Martin PJ, Zarling J, Kidd P, et al. Monoclonal antibody 1F5 (anti-CD20) serotherapy of human B cell lymphomas. Blood 1987;69:584-91.

18 Maloney DG, Grillo-Lopez AJ, White CA, Bodkin D, Schilder RJ, Neidhart JA, et al. IDEC-C2B8 (Rituximab) anti-CD20 monoclonal antibody therapy in patients with relapsed low-grade non-Hodgkin's lymphoma. Blood 1997;90:2188-95

19 McLaughlin P, Grillo-Lopez AJ, Link BK, Levy R, Czuczman MS, Williams ME, et al. Rituximab chimeric anti-CD20 monoclonal antibody therapy for relapsed indolent lymphoma: half of patients respond to a four-dose treatment program. J Clin Oncol 1998;16:2825-33.

20 Byrd JC, Kitada S, Flinn IW, Aron JL, Pearson M, Lucas D, et al. The mechanism of tumor cell clearance by rituximab in vivo in patients with $B$-cell chronic lymphocytic leukemia: evidence of caspase activation and apoptosis induction. Blood 2002;99:1038-43.

21 Farag SS, Flinn IW, Modali R, Lehman TA, Young D, Byrd JC. Fc gamma RIlla and Fc gamma Rlla polymorphisms do not predict response to rituximab in Bcell chronic lymphocytic leukemia. Blood 2004;103:1472-4

22 Jazirehi AR, Bonavida B. Cellular and molecular signal transduction pathways modulated by rituximab (rituxan, anti-CD20 mAb) in non-Hodgkin's lymphoma: implications in chemosensitization and therapeutic intervention. Oncogene 2005;24:2121-43.

23 Kuo CT, Veselits ML, Leiden JM. LKLF: A transcriptional regulator of singlepositive T cell quiescence and survival. Science 1997;277:1986-90.

24 Watanabe C, Shu GL, Zheng T, Flavell RA, Clark EA Caspase 6 regulates G0 to $\mathrm{G} 1$ entry into the cell cycle and activation in lymphocytes [abstract]. 2005 Keystone Symposium J8, 2005:165, no 234

25 Di Gaetano N, Cittera E, Nota R, Vecchi A, Grieco V, Scanziani E, et al. Complement activation determines the therapeutic activity of rituximab in vivo. J Immunol 2003;171:1581-7.

26 Cragg MS, Glennie MJ. Antibody specificity controls in vivo effector mechanisms of anti-CD20 reagents. Blood 2004;103:2738-43.

27 Bannerii R, Kitada S, Flinn IW, Pearson M, Young D, Reed JC, et al. Apoptotic-regulatory and complement-protecting protein expression in chronic lymphocytic leukemia: relationship to in vivo rituximab resistance. J Clin Oncol 2003;21:1466-71.

28 Teeling JL, French RR, Cragg MS, van den Brakel J, Pluyter M, Huang $\mathrm{H}$, et al. Characterization of new human CD2O monoclonal antibodies with potent cytolytic activity against non-Hodgkin lymphomas. Blood 2004;104:1793-800.

29 Van der Kolk LE, Grillo-Lopez AJ, Baars JW, Hack CE, van Oers MH. Complement activation plays a key role in the side-effects of rituximab treatment. Br J Haematol 2001;115:807-11.

30 Cartron G, Dacheux L, Salles G, Solal-Celigny P, Bardos P, Colombat P, et al. Therapeutic activity of humanized anti-CD20 monoclonal antibody and polymorphism in lgG Fc receptor FcgammaRIlla gene. Blood 2002;99:754-8.

31 Weng WK, Levy R. Two immunoglobulin $G$ fragment $C$ receptor polymorphisms independently predict response to rituximab in patients with follicular lymphoma. J Clin Oncol 2003;21:3940-7.

32 Clynes RA, Towers TL, Presta LG, Ravetch JV. Inhibitory Fc receptors modulate in vivo cytotoxicity against tumor targets. Nat Med 2000;6:443-6.

33 Uchida J, Hamaguchi Y, Oliver JA, Ravetch JV, Poe JC, Haas KM, et al. The innate mononuclear phagocyte network depletes B lymphocytes through $\mathrm{Fc}$ receptor-dependent mechanisms during anti-CD20 antibody immunotherapy. J Exp Med 2004; 199:1659-69.

34 Hernandez-Ilizaliturri FJ, Jupudy V, Ostberg J, Oflazoglu E, Huberman A, Repasky $\mathrm{E}$, et al. Neutrophils contribute to the biological antitumor activity of rituximab in a non-Hodgkin's lymphoma severe combined immunodeficiency mouse model. Clin Cancer Res 2003;9:5866-73.

35 Stockmeyer B, Dechant $M$, van Egmond M, Tutt AL, Sundarapandiyan K, Graziano RF, et al. Triggering Fc alpha-receptor I (CD89) recruits neutrophils as effector cells for CD20-directed antibody therapy. J Immunol 2000; 165:5954-61

36 Bernasconi NL, Traggiai E, Lanzavecchia A. Maintenance of serological memory by polyclonal activation of human memory B cells. Science 2002;298:2199-202.

37 Tsokos GC. B cells, be gone-B-cell depletion in the treatment of rheumatoid arthritis. N Engl J Med 2004;350:2546-8.

38 van Nierop K, de Groot C. Human follicular dendritic cells: function, origin and development. Semin Immunol 2002;14:251-7. 
39 Clark EA, Ledbetter JA. How B and T cells talk to each other Nature 1994;367:425-8.

40 Gong Q, Ou Q, Ye S, Lee WP, Cornelius J, Diehl L, et al. Importance of cellular microenvironment and circulatory dynamics in B cell immunotherapy. $\mathrm{J}$ Immunol 2005; 174:817-26.

41 Hamaguchi Y, Uchida J, Cain DW, Venturi GM, Poe JC, Haas KM, et al. The peritoneal cavity provides a protective niche for $\mathrm{B} 1$ and conventional $\mathrm{B}$ ymphocytes during anti-CD20 immunotherapy in mice. J Immunol 2005; 174:4389-99.
42 Fujimoto $M$, Poe JC, Hasegawa M, Tedder TF. CD19 regulates intrinsic $B$ lymphocyte signal transduction and activation through a novel mechanism of processive amplification. Immunol Res 2000;22:281-98.

43 Greten FR, Eckmann L, Greten TF, Park JM, Li ZW, Egan L, et al. IKKbeta links inflammation and tumorigenesis in a mouse model of colitis-associated cancer. Cell 2004;118:285-96.

44 Dave SS, Wright G, Tan B, Rosenwald A, Gascoyne RD, Chan WC, et al. Prediction of survival in follicular lymphoma based on molecular features of tumor-infiltrating immune cells. N Engl J Med 2004;351:2159-69. 